\title{
Effectiveness of spatial mosaic management for grassland breeding shorebirds
}

\author{
Ernst B. Oosterveld · Freek Nijland • \\ Cees J. M. Musters • Geert R. de Snoo
}

Received: 5 September 2009/Revised: 1 June 2010/ Accepted: 2 July 2010/Published online: 30 July 2010

(C) The Author(s) 2010. This article is published with open access at Springerlink.com

\begin{abstract}
Since 2000, a new management technique has been introduced to stop the rapid decline of grassland breeding shorebirds in the Netherlands, called 'mosaic management'. The most important difference from earlier Agri-Environment Schemes is that the mosaic management is conducted at a landscape scale (150-650 ha) rather than an individual farm scale (50-60 ha) and that there is purposeful planning of the spatial distribution and layout of management measures within a local area. We tested the effectiveness of the mosaic management by analysing breeding population trends of Northern Lapwing (Vanellus vanellus), Black-tailed Godwit (Limosa limosa), Redshank (Tringa totanus) and Oystercatcher (Haematopus ostralegus) in comparison with three other management types: individual management, regular farmland and nature reserves. After the introduction of mosaic management, populations of Black-tailed Godwit and Redshank
\end{abstract}

Communicated by F. Bairlein.

E. B. Oosterveld ( $₫)$

Altenburg \& Wymenga ecological consultants,

P.O. Box 32, 9269 ZR Feanwâlden, The Netherlands

e-mail: e.oosterveld@altwym.nl

F. Nijland

Weidevogelmeetnet Friesland, Bureau N,

Posthoornsteeg 1C, 8911 AS Leeuwarden, The Netherlands

C. J. M. Musters

Institute of Environmental Sciences, Department of Conservation Biology (CML-CB), Leiden University,

P.O. Box 9518, 2300 RA Leiden, The Netherlands

G. R. de Snoo

Wageningen University and Research,

Nature Conservation on Farmland, P.O. Box 47,

6700 AA Wageningen, The Netherlands stabilised and Northern Lapwing populations increased. Oystercatcher decreased, but this was also due to reduced winter survival. Populations in the mosaic management areas showed a greater annual improvement of $0-18 \%$ compared to other management types. The mosaic areas did not appear to be 'sink' areas as productivity in the mosaic areas seemed to be sufficient to support the observed densities. However, with the exception of Northern Lapwing, the change of trend was not greater in the mosaic areas than in the other management types. So, for the species other than Northern Lapwing, the good performance cannot be attributed to the mosaic management. The mosaic areas were good breeding habitats beforehand and continue to be so. It is possible that the mosaic management is part of the success, but not exclusively so. Our results show that modern farming can still be combined with grassland breeding shorebird management. However, further study of success factors is urgently needed for the conservation of the remaining good habitats on farmland and restoration of lost ones.

Keywords Shorebirds · Grassland management · Population development - Farmland birds .

Agri-environmental schemes

\section{Introduction}

In the Netherlands, most grassland breeding shorebird species are declining rapidly (Hagemeijer and Blair 1997; Teunissen and Soldaat 2006). The majority of the species: Northern Lapwing (Vanellus vanellus), Oystercatcher (Haematopus ostralegus), Redshank (Tringa totanus) and Black-tailed Godwit (Limosa l. limosa) breed on farmland (60-75\%; Teunissen and Soldaat 2006). The decline of 
these species reflects the adverse state of farmland birds in Europe, generally because of intensification of agriculture (e.g. Donald et al. 2001, 2008). To counter the negative biodiversity effects, Agri-Environmental Schemes (AES) have been introduced. For grassland breeding shorebirds, Dutch governments have tried to enhance population numbers-especially of the Black-tailed Godwit-since the 1980s by the introduction of these AES and the creation of nature reserves. Recently, it was shown that AES have limited effects on biodiversity Europewide (e.g. Kleijn et al. 2006), and this also applies to grassland breeding shorebirds in the Netherlands (Kleijn et al. 2001; Verhulst et al. 2007). Management agreements at the individual farmer level, consisting of a postponed mowing date for the protection of nests and chicks, had a very limited positive effect on breeding bird numbers compared to fields with no additional management measures. Moreover, if differences could be detected, they had already existed before the introduction of the AES (Kleijn and van Zuijlen 2004).

Because of these findings, there is a strong need for improvement of the effectiveness of AES in the Netherlands. Therefore, in 2000, a new management technique for grassland breeding shorebird conservation on farmland was introduced, the so-called 'spatial mosaic management' with planning on a regional scale. Within a region, farmers cooperate in their management to produce a mosaic of grassland types throughout the breeding season. The aim of the mosaic is to meet all the ecological requirements of the different grassland breeding shorebird species during the different stages of the breeding season: settlement, nesting, chick rearing and fledging. There are several management measures: creating shallow drains, nest protection, adapted mowing (early and postponed mowing with different periods, creating refuge strips at mowing, strip mowing, etc.) and adapted grazing (low-intensity, pre-grazing, etc.). The mosaic management is organised on areas of 100-1,500 ha and implemented by farmers' collectives. The most important difference with earlier AES at the individual farmer level is that the mosaic management is on a much larger scale and that there is purposeful planning of the spatial distribution and layout of management measures. The distribution of measures is adjusted to the spatial distribution of breeding birds and families after the chicks have left the nest and need another 3-4 weeks wandering around before fledging (Schekkerman 2008). The spatial coherency and heterogeneity are thought to be adequate innovations when compared to earlier AES, according to international experience (Benton et al. 2003; Whittingham 2007). Usually, in the Dutch grassland breeding shorebird AES, there is a special focus on the availability of tall grass for the chicks of the Black-tailed Godwit, so-called 'chick land'. The Black-tailed Godwit is a flagship species of the meadow bird community in The
Netherlands because ca. $40 \%$ of all European Black-tailed Godwits breed in The Netherlands (Teunissen and Soldaat 2006). Chick survival is the bottleneck in the demography of the species (Schekkerman et al. 2008).

Recently, we concluded that the new mosaic management performs better than the average regional and national trends (Oosterveld 2006). In the first 5 years after its introduction, Northern Lapwing, Oystercatcher and Redshank showed an annual increase of 6-7\%. This compares to an annual decrease of 2-6\% within the Friesian regional and the national trends. In the same period, Black-tailed Godwit fluctuated without a clear trend in the mosaic areas and decreased 4-9\% per year within the regional and national trends. This paper considers how the mosaic management has performed after 8 years and whether this new approach is indeed ecologically more effective for grassland breeding shorebirds than the 'traditional' management prescriptions contained in individual management agreements with farmers. To answer these questions, we focus on the trends in breeding bird numbers of Northern Lapwing, Oystercatcher, Redshank and Black-tailed Godwit in areas with the mosaic management compared with those on regular farmland, on areas with individual management agreements and on nature reserves. Because the mosaic management is focussed on the Black-tailed Godwit, especially positive effects on this species were expected.

\section{Methods}

\section{Study areas}

The study was carried out in the northern part of the Netherlands, the provinces of Friesland and Groningen. These provinces are among the most important regions for grassland breeding shorebirds in the Netherlands, with large areas of wet grassland. For the study, we selected eight areas with mosaic management. The mosaic areas were created for grassland breeding shorebird conservation and especially for the Black-tailed Godwit, which is highlighted in Dutch policy as a flagship species. The selection criteria for the mosaic areas were: (1) the availability of breeding bird data over a long period (at least since 1996), and (2) reasonable numbers of grassland breeding shorebirds present (so no marginal bird habitat). The eight research areas have an average size of 352 ha (total area 2,811 ha) and consist of wide open, wet grasslands on peat and clay soils (Table 1). The areas are used for modern dairy farming (average farm size and intensity comparable to the rest of the northern Netherlands: 40-60 ha, $\pm 12,000 \mathrm{~kg}$ milk/ha/year). In certain mosaic areas a small minority of other farm types are involved, 
Table 1 Features of the mosaic areas (this study, 2005) and the research plots for the other management types (cf. Weidevogel Meetnet Friesland, 2003-2005)

\begin{tabular}{|c|c|c|c|c|}
\hline & Mosaic management & Individual management & Regular farmland & Reserves \\
\hline Number of plots & 8 & 29 & 46 & 42 \\
\hline Area (ha, average \pm SD) & $352 \pm 181 \mathrm{a}$ & $59 \pm 19 b$ & $63 \pm 23 b$ & $62 \pm 30 \mathrm{~b}$ \\
\hline \multicolumn{5}{|c|}{ Mosaic features (\% of total area \pm SD) } \\
\hline Mowing after $23 / 5$ & $3.3 \pm 4.7 \mathrm{a}$ & $0 \mathrm{~b}$ & $0 \mathrm{~b}$ & $0 \mathrm{~b}$ \\
\hline Mowing after $1 / 6$ and $8 / 6$ & $9.3 \pm 7.6 \mathrm{a}$ & $13.2 \pm 5.8 b$ & $0 \mathrm{c}$ & $0 \mathrm{c}$ \\
\hline Mowing after $15 / 6$ and $22 / 6$ & $7.3 \pm 7.6 \mathrm{a}$ & $15.9 \pm 7.6 \mathrm{~b}$ & $0 \mathrm{c}$ & $80-90 \mathrm{~d}$ \\
\hline Refuge strips & $6.5 \pm 8.5 \mathrm{a}$ & $0 \mathrm{~b}$ & $0 \mathrm{~b}$ & $0 \mathrm{~b}$ \\
\hline Additional nest protection & $75 \pm 11.9 \mathrm{a}$ & $80.5 \pm 8.7 \mathrm{a}$ & No data & $0 \mathrm{~b}$ \\
\hline
\end{tabular}

Letters in the columns refer to significance of the differences between the types within the measurements: different letters mean significant differences, corresponding letters refer to non-significant differences; area, mowing $1+8 / 6$, mowing $15+22 / 6: t$ test, $P<0.001$; mowing $23 / 5$, refuge strips, nest protection: Mann-Whitney test, $P<0.001$ )

such as organic, sheep and beef cattle farms. Mosaic management started in five areas in 2000 and in three areas in 2001 .

For a comparison with the other management types, data were used from the regional grassland breeding shorebird monitoring program of the province of Friesland (Weidevogel Meetnet Friesland, WMF). This is a meaningful comparison because (1) six out of eight mosaic areas are in Friesland, and (2) Friesland is one of the two most important areas for breeding shorebirds of grassland in the Netherlands. In total, the WMF has 117 plots that are ca. 60 ha on average. For the purpose of this study, the plots were split into the categories 'individual management', 'regular farmland' and 'nature reserve' (Table 1).

\section{Bird data}

The available grassland breeding shorebird data from the eight mosaic areas were time series of numbers of nests (five areas) or breeding pairs (three areas) over the years 1996-2008. The data were gathered by volunteers during nest protection activities or during censuses. Although the data are of a different kind (nests and breeding pairs), trends could be compared because every area was consistently counted with the same method. Breeding pairs on the WMF plots were counted by volunteers by the Dutch standardised method (Van Dijk 2004), comparable to that used in the Common Bird Census in the UK.

\section{Data analysis}

To assess the quality of the mosaic areas for the four grassland breeding shorebird species, we used a stepwise approach. First, we compared breeding densities of the mosaic areas with those of individual management agreements, regular farmland and nature reserves in Friesland in the 2 years before the effects of the mosaic management could be detected (1999 and 2000). Because mosaic management started in five areas in 2000 and three areas in 2001, we calculated the average over 1999-2000 and 1999-2001, respectively (in the last case, data of 2000 were missing). In five mosaic areas only nest data were available. For these areas, bird densities were calculated according to Wymenga et al. (2000) ${ }^{1}$ : for Northern Lapwing with the formula $19.788+(0.555 \times$ nest density $)-(0.0648 \times$ area), for Black-tailed Godwit $10.827+(0.905 \times$ nest density), for Redshank $4.976+(1.442 \times$ nest density $)$ and for Oystercatcher $9.950+(1.135 \times$ nest density $)-$ $(0.0566 \times$ area $)$.

Secondly, the population trends in the mosaic areas were compared to those with the other grassland management types in the province of Friesland in a betweentreatments comparison. For the nature reserve category only plots were used in reserves that were specifically managed for grassland breeding shorebirds. No plots on individual management and on regular farmland were included which were embedded in the mosaic management after 2000.

Statistical analyses were carried out with a generalised linear model (GLM) in GenStat on the number of nests or breeding pairs, with management category, management period (1996-1999 and 2000-2008) and year as fixed factors and plot as a random factor. Analysis of the

\footnotetext{
${ }^{1}$ In this study, relationships were calculated between the number of nests found and the number of breeding pairs according to territory mapping in the same grassland area. The dataset is from ca. 115 areas throughout the Netherlands, in which the data of nests and breeding pairs were gathered independently and in the same year, mainly in the period 1996-1998. By analysis of variance, the influence of area and extreme values were tested. The best fitting models were used for the calculations. This explains why, for Northern Lapwing and Oystercatcher, the formula contains an area component but not for Blacktailed Godwit and Redshank. Correlation coefficients $R^{2}$ are: Oystercatcher $66.9 \%$, Black-tailed Godwit $67.7 \%$, Redshank $46 \%$, Northern Lapwing $52.8 \%$.
} 
residuals showed that the nest and pair data were best represented by a Poisson distribution. Regression coefficients of the trend in numbers over the years were estimated ( \pm standard error) to assess annual population change for every species for every separate management type, over the periods before and after introduction of the mosaic management (1996-1999 and 2000-2008). Differences from zero of regression coefficients and differences between coefficients were tested with a $t$ test. Differences between breeding densities were tested by comparing the $95 \%$ confidence limits, calculated as average \pm 1.96 times standard error.

\section{Results}

\section{Management types}

Table 1 shows the management characteristics of the plots in the different categories. The study areas with mosaic management average ca. 350 ha, the plots for the other management types average ca. 60 ha. The mosaic areas are characterised by a relatively large area of the grassland type "Mowing after May 23", moderate areas of "Mowing in June", many "Refuge strips" and a large area of "Nest protection". The plots with individual management are distinguished by much "Mowing in June" and a large proportion of "Nest protection". Regular farmland is characterised by no grassland breeding shorebird protection measures at all and the nature reserves are characterised by almost only "Mowing after half June".

Bird densities before the introduction of the mosaic management

In the 2 years before mosaic management (1999-2000 or 1999-2001), we found on average per 100 ha: 30.8 breeding pairs of Northern Lapwing, 23.6 pairs of Godwit, 18.1 pairs of Redshank and 18.4 pairs of Oystercatcher in the mosaic areas (Fig. 1). For the Oystercatcher, no significant differences between the different management types were found. Northern Lapwing densities in the (future) mosaic areas were significantly higher compared to individual management and regular farmland and lower than the nature reserves. For the Black-tailed Godwit, densities in the areas with (future) mosaic management were not different from individual management and regular farmland, but significantly higher numbers were found in the nature reserves. Finally, for the Redshank, the numbers in the (future) mosaic areas and the nature reserves were significantly higher compared to individual management and regular farmland.
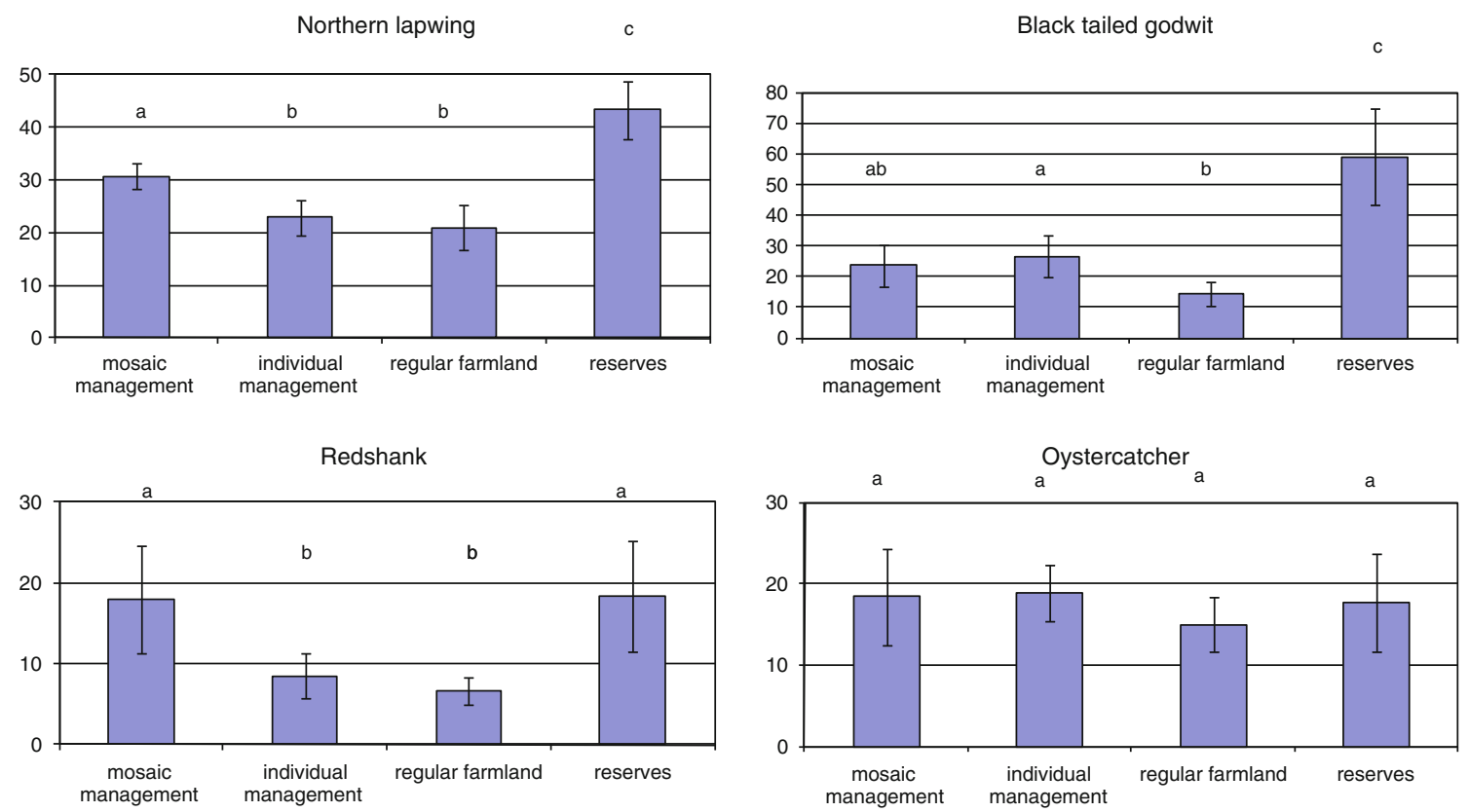

Fig. 1 Average densities (breeding pairs per 100 ha, with 95\% Cl) of the four grassland breeding shorebird species in the areas with mosaic management $(n=8)$, compared to areas with individual management $(n=29)$, on regular farmland $(n=46)$ and in nature reserves $(n=42)$ in Friesland at the start of the mosaic management (1999-2000; 1999-2001 for three mosaic areas that started in

2001). Different letters $(a, b, c)$ refer to significant differences $(P<0.05$ on the basis of $95 \%-\mathrm{Cl})$; corresponding letters refer to non-significant differences. Data about individual management, regular farmland and reserves from Weidevogel Meetnet Friesland (WMF) 
Bird trends before and after introduction of mosaic management

In Fig. 2 the population trends of the grassland breeding shorebirds in the mosaic areas are presented. Black-tailed Godwit and Redshank populations showed no significant change from zero before or after introduction of the mosaic management (Table 2) (Black-tailed Godwit before: $T=-0.85, \quad d f=980, \quad P=0.395 ; \quad$ after: $\quad T=-1.59$, $d f=980, \quad P=0.112 ; \quad$ Redshank before: $\quad T=1.64$, $d f=979, \quad P=0.102 ; \quad$ after: $\quad T=1.35, \quad d f=979$, $P=0.177)$. Oystercatcher populations showed no change before introduction $(T=0.23, d f=979, P=0.820)$, but decreased afterwards by $2 \%$ per year $(T=-2.46$, $d f=979, \quad P=0.014)$. Northern Lapwing populations decreased by $7 \%$ per year before $(T=-1.71, d f=979$, $P=0.087$, close to statistical significance) and increased by $4 \%$ per year after introduction $(T=4.83, d f=979$, $P=<0.001)$.
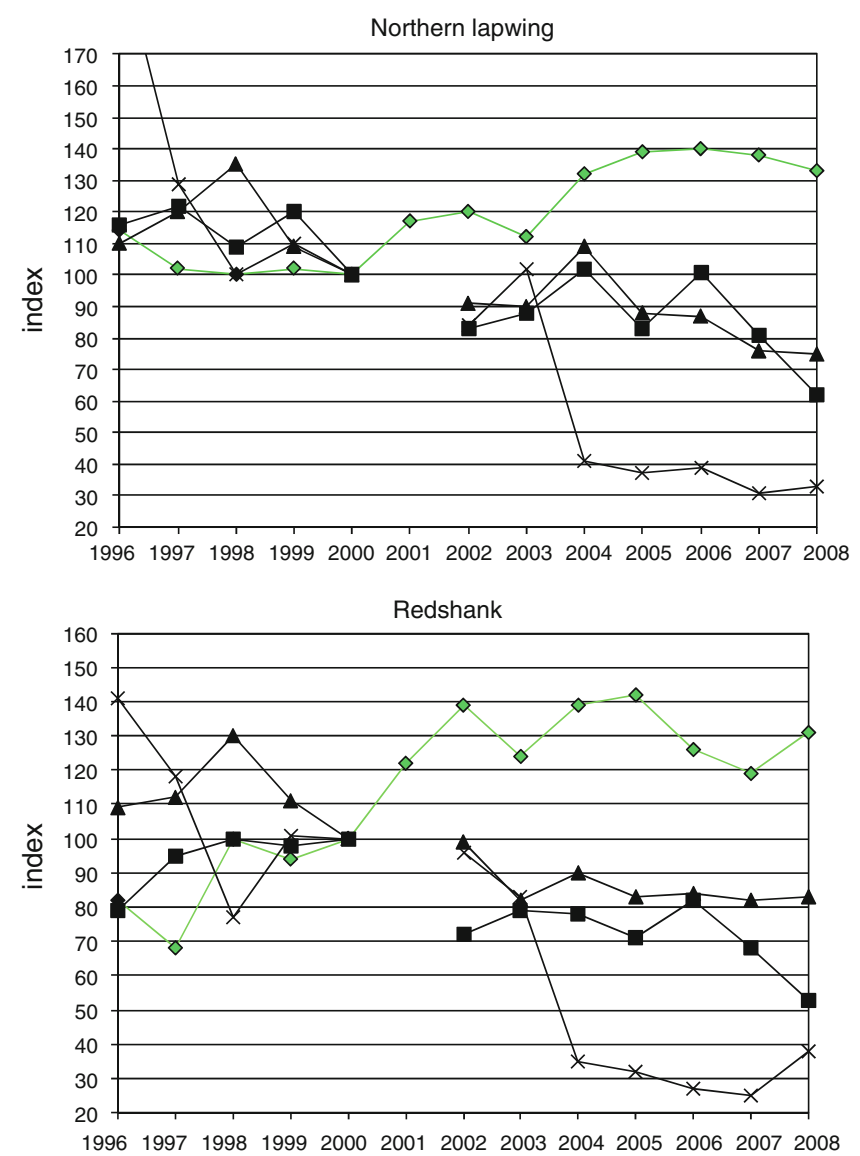

Only for Northern Lapwing is the change of trend (\% annual population change) before and after the introduction significant (from $-7 \%$ to $+4 \%, T=2.64, d f=979$, $P=0.008)$. With the other species, no significant change of trend after the introduction of mosaic management is found (Black-tailed Godwit $T=-1.20, \quad d f=980$, $P=0.230$, Redshank $T=-1.29, d f=979, P=0.197$, Oystercatcher $T=-0.84, d f=979, P=0.398)$.

\section{Comparisons with other management types}

Before introduction of the mosaic management, the trends of the grassland breeding shorebird species in the (future) mosaic areas were already generally better than with the other management types. The exception was Northern Lapwing in regular farmland and reserves (Table 2a). After introduction of the mosaic management, the positive differences in trend persisted to different degrees [Table 2b, afterwards more differences are statistically
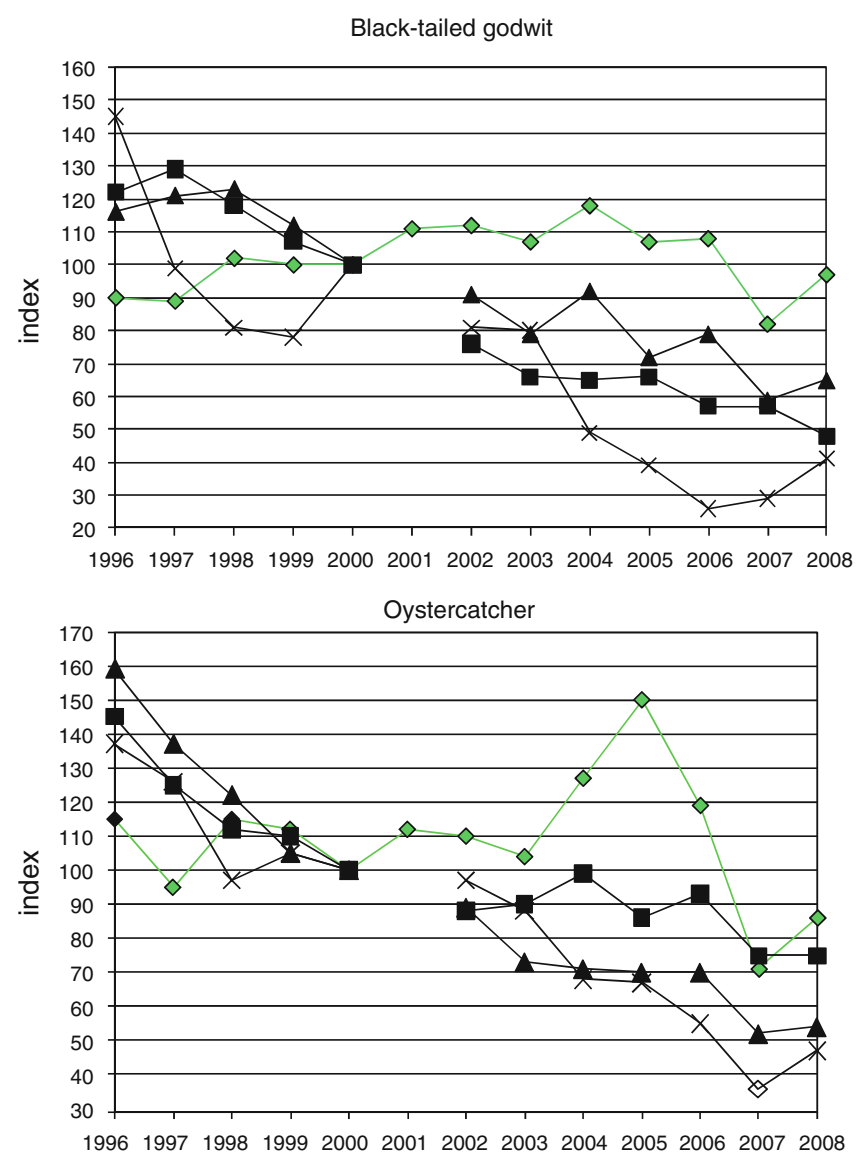

$$
\diamond \text { mosaic management } \neg \text { reserves }
$$

- regular farmland $\quad *$ individual management

Fig. 2 Trends of the four grassland breeding shorebird species in the areas with mosaic management compared to regular farmland, reserves and areas with individual management in Friesland before (1996-1999) and after (2000-2008) introduction of the mosaic management. Data of the other management types are from Weidevogel Meetnet Friesland (WMF). $2000=$ the start of the mosaic management $=$ index 100. N.B. in WMF, there are no data for 2001 because of foot and mouth disease 
Table 2 Average annual population change (\%, from linear trend) of the four grassland breeding shorebird species in the mosaic areas (blank columns) and differences of this change with regular farmland, nature reserves and individual management (grey columns) in Friesland before (A) and after (B) the year of introduction of the mosaic management

\begin{tabular}{|c|c|c|c|c|c|c|c|c|}
\hline & \multicolumn{4}{|c|}{ A before in troduction of mosaic management } & \multicolumn{4}{|c|}{ B after introduction of mosaic management } \\
\hline & $\begin{array}{l}\text { annual } \\
\text { change } \\
\text { (future) }\end{array}$ & $\begin{array}{l}\text { difference } \\
\text { with mosai }\end{array}$ & $\begin{array}{l}\% \text { ) of ann } \\
\text { managen }\end{array}$ & $\begin{array}{l}\text { al change } \\
\text { ent }\end{array}$ & $\begin{array}{l}\text { annual } \\
\text { change }\end{array}$ & $\begin{array}{l}\text { difference } \\
\text { with mosa }\end{array}$ & $\begin{array}{l}\text { \%) of ann } \\
\text { c manage }\end{array}$ & ial change \\
\hline species & $\begin{array}{c}\text { management } \\
(\%)\end{array}$ & $\begin{array}{l}\text { regular } \\
\text { farmland }\end{array}$ & $\begin{array}{l}\text { nature } \\
\text { reserves }\end{array}$ & $\begin{array}{l}\text { individual } \\
\text { management }\end{array}$ & $\begin{array}{c}\text { management } \\
(\%)\end{array}$ & $\begin{array}{l}\text { regular } \\
\text { farmland }\end{array}$ & $\begin{array}{l}\text { nature } \\
\text { reserves }\end{array}$ & $\begin{array}{c}\text { individual } \\
\text { management }\end{array}$ \\
\hline Northern Lapwing & $-7(*)$ & $+2^{\text {n.s. }}$ & $+4^{\text {n.s. }}$ & $-7^{\text {n.s. }}$ & $+4 * *$ & $-8 * * *$ & $-7 * * *$ & $-15 * * *$ \\
\hline Black-tailed Godwit & $+4^{\text {n.s. }}$ & $-10^{\text {n.s. }}$ & $-6^{\text {n.s. }}$ & $-6^{*}$ & $-2^{\text {n.s. }}$ & $-7 * *$ & $-4 * *$ & $-13 * * *$ \\
\hline Redshank & $+7^{\text {n.s. }}$ & $-7^{\text {n.s. }}$ & $-7^{\text {n.s. }}$ & $-13^{\text {n.s. }}$ & $+1^{\text {n.s. }}$ & $-8 * *$ & $-4 * *$ & $-18^{* * * *}$ \\
\hline Oystercatcher & $+1^{\text {n.s. }}$ & $-12 *$ & $-15 * * *$ & $-9^{\text {n.s. }}$ & $-2 *$ & $-2^{\text {n.s. }}$ & $-6 * * *$ & $-8 * * *$ \\
\hline
\end{tabular}

A difference of +2 for regular farmland (first grey column table A) means that the annual population change on regular farmland is $2 \%$ better than with mosaic management. In bold are the differences between mosaic management and the other management types that increased after introduction of the mosaic management. $* P<0.10$; $* P<0.05$; ** $P<0.01$; *** $P<0.001$; n.s. not significant

Table 3 Change of trend (\% average annual population change, from linear trend) of the four grassland breeding shorebird species after the year of introduction of the mosaic management for the management types mosaic management, regular farmland, nature reserves and individual management in Friesland

\begin{tabular}{lllcc}
\hline Management type & Northern Lapwing & Black-tailed Godwit & Redshank & Oystercatcher \\
\hline Mosaic management & $+10^{* *}$ & -5 & -6 & -3 \\
Individual management & +2 & -1 & -10 & -2 \\
Nature reserves & -1 & -3 & -3 & $+7 * *$ \\
Regular farmland & +1 & -3 & -6 & +7 \\
\hline
\end{tabular}

** $P<0.01$, all other change of trend values were non-significant

significant, but this is, above all, a matter of more data points ( 8 years instead of four) that increase the chance of statistical significance]. With Black-tailed Godwit, Redshank and Oystercatcher, some differences increased and some decreased. Only with Northern Lapwing did all trend differences of mosaic management with the other management types increase (Table 2b). For Black-tailed Godwit, Redshank and Northern Lapwing (but not for Oystercatcher), the trend difference with individual management increased.

However, only for Northern Lapwing did the change of trend after introduction of the mosaic management get significantly better than the change of trend associated with the other management types (Table 3 ). For the other species, there was no difference in change of trend between the management types, with the exception of Oystercatcher in the nature reserves.

\section{Discussion and conclusions}

In 1975, the first policy paper related to biodiversity conservation on farmland was published in the Netherlands aiming at enhancing grassland breeding shorebirds on both farmland and nature reserves. Since then, Dutch governments have tried to improve conservation efforts for these birds. At the start, relatively simple measures were taken, such as nest protection, postponed mowing and grazing types on individual farms: breeding birds as a 'farm product' (cf. Musters et al. 2001). Nowadays, a more system-oriented approach is being developed, taking into account all relevant breeding stages of the birds (settlement, nesting, non-fledging, fledging) on a much larger spatial scale. The result is spatial mosaic management beyond individual farm level, within which farmer collectives try to optimise their Agri-Environmental 
management. Our study assesses the results of this mosaic management for the first time, using data collected over 8 years during which one may expect effects to show at the population level.

Does mosaic management improve bird populations?

After the introduction of the mosaic management, only the trend for Northern Lapwing changed from negative to positive. The trends for the other three species did not significantly change, nor was the change better than that of the other management types. So, the results suggest that the mosaic management only worked for Northern Lapwing. This conclusion is surprising, because the mosaic management is especially aimed at the ecological requirements of the Black-tailed Godwit, the flagship species of the Dutch meadowbird community. The core of the mosaic management is to realize enough, spatially well situated, 'chick land' (tall grass suited for godwit chick survival). Northern Lapwings with their chicks avoid tall grass, but this species may benefit from other ingredients of the mosaic management, such as intensive nest protection and grazing. Northern Lapwing families prefer grazed fields, because of the short vegetation and probably because they run a smaller risk of predation there (Schekkerman et al. 2009).

Does spatial mosaic management perform better than individual management?

An important question is whether the coordinated, largescale, mosaic management shows better population trends than individual management at the farm level. Our results show positive differences in trend in favour of the mosaic areas already present before the introduction of the mosaic management (only significant for Black-tailed Godwit, lack of significance for the other species is mainly because of small sample sizes). Afterwards, the differences still increased significantly for all species to $8-18 \%$ (Table $2 b$ ). So the populations in the mosaic areas performed better than with individual management, but we believe that this result was not due to the mosaic management. So, what may explain the better performance?

\section{Sustaining good breeding areas}

For a sound comparison between the grassland breeding shorebird trends in the mosaic areas and the other management types, we investigated breeding densities and population trends before the start of the mosaic experiments. It was found that, in most cases, breeding densities in the (future) mosaic management areas were better than in regular farmland and with individual management but worse than in nature reserves. Also, better trends were found beforehand in the mosaic areas compared to the other management types (with the exception of Northern Lapwing). So it must be concluded that the mosaic areas were already good grassland breeding shorebird habitats at the start of the experiment and that they still were afterwards. This is in line with earlier studies (e.g Kleijn and van Zuijlen 2004; Verhulst et al. 2007). The mosaic management was only of significant influence for Northern Lapwing, but the persistence of Black-tailed Godwit and Redshank populations is a good result given the negative general trends (Oosterveld 2006) and the strongly negative trends with the other management types. The decrease of the Oystercatcher is a general phenomenon and is partly related to less favourable winter conditions in the Wadden Sea (Hulscher and Verhulst 2003).

Is immigration involved?

The evidently good breeding habitat of the mosaic areas may attract breeding birds from the surrounding area. This would mean that the population increases are not the result of a reproductive surplus but of immigration, and that the mosaic areas are so-called 'sink' populations (e.g. Watkinson and Sutherland 1995). To evaluate this, we have indications of reproductive success for Black-tailed Godwit and Redshank from 18-44 plots over 2006-2008 from Weidevogelmeetnet Friesland. Ca. 50\% of the plots were in our mosaic areas and the rest was from areas with comparable management as in the mosaic areas. The indications come from calculations of so-called Gross Territorial Success GTS. ${ }^{2}$ For Black-tailed Godwit, the average GTS over 2006-2008 in the mosaic plots was 58\%. This was comparable to the GTS with individual management $(45 \%$, ANOVA post hoc test with Bonferroni correction, difference not significant) and on regular farmland (52\%, ANOVA post hoc test with Bonferroni correction, difference not significant), but higher than GTS for reserves (49\%, ANOVA post hoc test with Bonferroni correction, $P<0.001)$. GTS of $58 \%$ is probably sufficient for a stable population (see footnote 2 for critical values) in the mosaic plots. For Redshank, the average GTS in the mosaic plots

\footnotetext{
${ }^{2}$ GTS is the number of alarming pairs during the week in which the first chicks fledge, as a percentage of the number of breeding pairs. GTS is an indicator of reproductive success of a population in a specific area (not an exact estimator). From the relationships between GTS and population trend and from GTS and chick survival (measured by radio tagging) in a population model, it can be shown that GTS $<50 \%$ is insufficient for a stable population, GTS $50-65 \%$ is probably sufficient and GTS $\geq 65 \%$ is sufficient (F. Nijland, H. Schekkerman, W. Teunissen, in preparation). Similar to Black-tailed Godwit, it can be calculated that for Redshank GTS $<43 \%$ is insufficient, $43-50 \%$ is probably sufficient and GTS $\geq 50 \%$ is sufficient for a stable population (F. Nijland).
} 
was $57 \%$, which was not significantly different from GTS in the other management types (ANOVA post hoc test with Bonferroni correction, $P>0.05$ ). GTS of $57 \%$ for Redshank indicates sufficient reproduction for a stable population. These results are only from 3 years, but they suggest that local reproduction in mosaic areas was more or less sufficient for Black-tailed Godwit and good for Redshank, and that the mosaic areas were not mere sink areas.

Schekkerman et al. (2008) also reported on the reproduction of the Black-tailed Godwit with mosaic management. Their study had a national scope but also involved three of the Frisian mosaic areas. They concluded that the areas with mosaic management performed better than control areas, but that reproduction was still not enough to compensate for adult mortality, with one exception: one of the Frisian areas in this study. The reason for the discrepancy with our findings may be that the years 2003-2005 in the Schekkerman et al. study were years with a relatively poor reproduction because of a high predation rate.

\section{Key factors}

Although mosaic management appears not to be of conclusive significance, it may contribute to sustaining the quality of the breeding habitat. But there are clearly other factors. The following factors have been identified as key factors for viable grassland breeding shorebird populations in Dutch grasslands (Schekkerman and Müskens 2000; Kleijn and van Zuijlen 2004; Wymenga et al. 2006; Verhulst et al. 2007; Schekkerman and Beintema 2007; Melman et al. 2008; Schekkerman et al. 2008):

- Openness of the landscape (because of preferred habitat for settling and because of interaction of landscape features such as trees with predation);

- Disturbance from roads, buildings, etc.;

- Groundwater level (related to food availability and vegetation structure);

- Nest protection;

- Amount and spatial arrangement (mosaic) of short and tall and structure-rich grass accessible for chicks (related to food and shelter availability), manipulated by groundwater level and fertilization;

- Soil quality (related to food availability and vegetation structure).

We did not study factors other than grassland management, so we do not know to what extent the other factors contribute to the quality of the breeding habitat in the mosaic areas. One aspect of the mosaic management is relevant to this discussion: the amount of late mown grass necessary within mosaic management. A number of studies (compiled in Oosterveld 2009) conclude that $29-50 \%$ of the grassland area should be mown late for Black-tailed Godwits to have sufficient productivity. The mosaic areas in this study had on average $16.6 \%$ late mown grass (Table 1 ). So the mosaic areas show a persisting population of Black-tailed Godwits with reasonable reproduction although they have considerably smaller quantities of postponed mowing than is usually considered necessary. Oosterveld (2009) concludes that the studies, in fact, do not differ very much in their conclusions and that the percentages are a matter of scale. The author suggests that establishing the minimum area of tall grass per godwit family necessary for the young to fledge (the "chick land') is much more important than the percentage within the overall landscape.

For grassland breeding shorebirds, it is not shown unequivocally from this study that better spatially coherent management (sensu Whittingham 2007) and more spatial heterogeneity (sensu Benton et al. 2003) are key factors, although they may have positive effects (for Northern Lapwing). For the target species of the mosaic management, Black-tailed Godwit, they seemed not to be conclusive.

\section{Conservation perspective}

A very clear conservation perspective from this study is to concentrate conservation efforts on the remaining good breeding areas. The importance of targeting existing populations for AES to be effective was highlighted previously by Vickery et al. (2004). Although we still do not know which are the predominant success factors, introducing mosaic management in these areas seems relevant in order to increase populations of Northern Lapwing. Possibly, mosaic management is also one of the factors (but not the conclusive one) for the conservation of the other grassland breeding shorebird species in these areas, including Blacktailed Godwit. We know from an earlier study that a sufficient amount of chick land (a major aspect of the mosaic management) is important for Black-tailed Godwit chick survival (Schekkerman et al. 2008). The results of the mosaic areas show that modern farming can still be combined with grassland breeding shorebird management. However, a further study of success factors in the mosaic areas is urgently needed for conservation of the remaining good habitats on farmland and probably restoration of lost ones (sensu Aebischer et al. 2000).

\section{Zusammenfassung}

Die Wirksamkeit eines räumlichen

Mosaikmanagements für Wiesenlimikolen

Um den schnellen Rückgang der Wiesenlimikolen in den Niederlanden zu stoppen, wurde im Jahr 2000 eine neue Methode, das "Mosaikmanagement" eingeführt. Der 
wichtigste Unterschied zur alten "Agri-Environment"Methode ist, dass das Mosaikmanagement auf der Ebene ganzer Landschaften (150-650 ha) statt nur auf individuellen Farmen (50-60 ha) betrieben wird und dass gezielte Planung der Verteilung und Anordnung der Maßnahmen in den betreffenden Landstrichen zugrunde liegt. Wir testeten die Wirksamkeit des Mosaikmanagement, indem wir die Entwicklung der Brutbestände von Kiebitz (Vanellus vanellus), Uferschnepfe (Limosa limosa), Rotschenkel (Tringa totanus) und Austernfischer (Haematopus ostralegus) mit der Entwicklung in Gebieten verglichen, die drei anderen Bewirtschaftungsmethoden unterlagen, nämlich individuelle Bewirtschaftung, Farmland und Naturschutzgebieten. Nach der Einführung des Mosaikmanagements stabilisierten sich die Bestände von Uferschnepfe und Rotschenkel, während sich die Kiebitzbestände sogar erhöhten. Die Bestände der Austernfischer sanken, was aber auch daran lag, dass ihre Winterüberlebensrate gesunken war. Populationen in Gebieten mit Mosaikmanagement hatten einen höheren jährlichen Zuwachs von 0-18\% verglichen mit anderen Bewirtschaftungsformen. Die Gebiete mit Mosaikmanagement waren keine "Sink"Habitate, da die Produktivität in diesen Gebieten ausreichte, um die beobachteten Bestände hervorzubringen. Mit Ausnahme der Kiebitze waren die Änderungen in den Trends allerdings nicht stärker, als in den Vergleichsgebieten. Daher ist das Mosaikmanagement außer bei Kiebitzen nicht für den guten Bruterfolg ausschlaggebend. Die Mosaik-Gebiete waren und blieben gute Brutgebiete. Es ist möglich, dass das Mosaikmanagement zu den erfolgreichen Jahren beigetraten hat, aber es war nicht der einzige Faktor. Unsere Ergebnisse zeigen, dass moderne Landwirtschaft noch immer mit dem Schutz grasbrütender Küstenvögel vereinbar ist. Eine weiterführende Untersuchung der ausschlaggebenden Faktoren ist für die Erhaltung der verbleibenden guten Brutgebiete und der Instandsetzung neuer Gebiete dringend erforderlich.

Acknowledgments We thank BoerenNatuur for making available the mosaic data and Dries Kuijper for additional statistical analysis. Grants for this study were obtained from BoerenNatuur and from Wageningen University, Nature Conservation of Farmland chair.

Open Access This article is distributed under the terms of the Creative Commons Attribution Noncommercial License which permits any noncommercial use, distribution, and reproduction in any medium, provided the original author(s) and source are credited.

\section{References}

Aebischer NJ, Green RE, Evans AD (2000) From science to recovery: four case studies of how research has been translated into conservatiom action in the UK. In: Aebischer NJ, Evans AD,
Grice PV, Vickery JA (eds) Ecology and conservation of lowland farmland birds. British Ornithological Union, Tring, pp 43-54

Benton TG, Vickery JA, Wilson JD (2003) Farmland biodiversity: is habitat heterogeneity the key? Trends Ecol Evol 18:182-188

Donald PF, Green RE, Heath MF (2001) Agricultural intensification and the collapse of Europe's farmland bird populations. Proc R Soc Lond B 268:25-29

Donald PF, Sanderson FJ, Burfield IJ, van Bommel FPJ (2008) Further evidence of continent-wide impacts of agricultural intensification on European farmland birds. Agric Ecos Environ 116:189-196

Hagemeijer EJM, Blair MJ (eds) (1997) The EBCC Atlas of European breeding birds: their distribution and abundance. Poyser, London

Hulscher JB, Verhulst S (2003) Opkomst en neergang van de Scholekster Haematopus ostralegus in Friesland in 1996-2000. Limosa 76:11-22 (with English summary)

Kleijn D, van Zuijlen GJC (2004) The conservation effects of meadow bird agreements on farmland in Zeeland, the Netherlands, in the period 1989-1995. Biol Conserv 117:443-451

Kleijn D, Berendse F, Smit F, Gilissen G (2001) Agri-environment schemes do not effectivily protect biodiversity in Dutch agricultural landscapes. Nature 413:723-725

Kleijn D, Baquero RA, Clough Y, Diaz M, De Esteban J et al (2006) Mixed biodiversity benefits of agri-environment schemes in five European countries. Ecol Lett 9:243-254

Melman ThCP, Schotman AGM, Hunink S, de Snoo GR (2008) Evaluation of meadow bird management especially black-tailed godwit Limosa limosa L., in the Netherlands. J Nat Conserv 16:88-95

Musters CJM, Kruk M, de Graaf HJ, ter Keurs WJ (2001) Breeding birds as a farm product. Conserv Biol 15:363-369

Oosterveld EB (2006) Weidevogelmozaïekbeheer in Noord-Nederland 2000-2005. De Levende Natuur 107:130-133 (with English summary)

Oosterveld EB (2009) Effectief weidevogelbeheer: naar een doeltreffender inzet van zwaar beheer. De Levende Natuur 110:188-191 (with English summary)

Schekkerman H. (2008) Precocial problems. PhD thesis, University of Groningen, The Netherlands

Schekkerman H, Beintema AJ (2007) Abundance of invertebrates and foraging success of black-tailed godwit Limosa limosa chicks in relation to agricultural grassland management. Ardea 95:39-54

Schekkerman H, Müskens GJDM (2000) Produceren Grutto's Limosa limosa in agrarisch grasland voldoende jongen voor een duurzame populatie? Limosa 73:121-134 (with English summary)

Schekkerman H, Teunissen W, Oosterveld E (2008) The effect of 'mosaic management' on the demography of black-tailed godwit Limosa limosa on farmland. J Appl Ecol 45:1067-1075

Schekkerman H, Teunissen W, Oosterveld E (2009) Mortality of black-tailed godwit Limosa limosa and northern lapwing Vanellus vanellus chicks: influence of predation and agriculture. J Ornithol 150:133-145

Teunissen WA, Soldaat LL (2006) Recente aantalsontwikkeling van weidevogels in Nederland. De Levende Natuur 107:70-74 (with English summary)

Van Dijk AJ (2004) Handleiding Broedvogel monitoring project. SOVON Vogelonderzoek Nederland, Beek Ubbergen

Verhulst J, Kleijn D, Berendse F (2007) Direct and indirect effects of the most widely implemented Dutch agri-environment schemes on breeding shorebirds. J Appl Ecol 44:70-80

Vickery JA, Bradbury RB, Henderson IG, Eaton MA, Grice PV (2004) The role of agri-environment schemes and farm management practices in reversing the farmland birds in England. Biol Conserv 119:19-39 
Watkinson AR, Sutherland WJ (1995) Sources, sinks and pseudosinks. J Anim Ecol 64:126-130

Whittingham MJ (2007) Will agri-environment schemes deliver substantial biodiversity gain, and if not why not? J Appl Ecol $44: 1-5$

Wymenga E, Griffioen R, Engelmoer M (2000) Meten van resultaten van collectieve weidevogelpakketten in de subsidieregeling agrarisch natuurbeheer. A and W-report 226. Altenburg \& Wymenga, Veenwouden

Wymenga E, Oosterveld EB, Bruinzeel L (2006) Management of meadow bird communities in Fryslân. Bottlenecks and solutions in the core areas of the black-tailed godwit. A and W-report 911. Altenburg \& Wymenga, Veenwouden 